\title{
A Chemical Overview of Azanza garckeana
}

\author{
Yilni Edward Bioltif ${ }^{1, *}$, Naanma Bioltif Edward ${ }^{2}$, Terry Dalyop Tyeng ${ }^{1}$ \\ ${ }^{1}$ Department of Chemistry, Faculty of Natural Science, Plateau State University, Bokkos, Nigeria. \\ ${ }^{2}$ Department of Plant Science and Biotechnology, Faculty of Natural Science, University of Jos, Nigeria. \\ Corresponding author* \\ edwardyilni405@gmail.com
}

Manuscript received: 18 May, 2020. Revision accepted: 10 November, 2020. Published: 17 November, 2020.

\begin{abstract}
Azanza garckeana is a popular fruit tree in Nigeria, specifically in Gombe State, where it is locally called 'goron tula' which means 'Kola of Tula'. It is also found in part of some African countries. Different plant part of this small tree/shrub has recorded different uses by the locals; uses ranging from its fruits being edible and others parts helping to remedy different diseases, especially sexually related diseases. It also records use as booster for sexual performance. The uses of the plant are majorly attributed to the presence of chemicals. Its local use initiates the necessity of this review to enhance the research for drug discovery since Chemicals are the chief constituencies responsible for its medicinal importance.
\end{abstract}

Keywords: Azanza garckeana; Chemical; Compounds; Mansonone.

\section{INTRODUCTION}

The indigenous fruits collected from the wild play a significant role in food and nutrient security of the poor and rural dwellers. Some wild fruits have been identified to have better nutritional value than cultivated fruits (Musinguzi et al., 2007) As a result, in recent years, a growing interest has emerged to evaluate various wild edible plants for their nutritional features (Nkafamiya, 2007; Aberoumand and Deokule, 2009; Nazarudeen, 2010). Nutritional value of indigenous fruit bearing tree species indicates that many are rich in sugars, essential vitamins and minerals, while others are high in vegetable oil and protein contents. In addition to fruit production and cash, the extensive list of benefits includes firewood, fodder, building material, shade and medicine especially to rural communities. Edible wild leaves and fruits are consumed frequently in Northern Nigeria especially in rural communities where a variety of edible leaves and fruits abound. Some of these are cultivated while others grow in the wild (Nkafamiya et al. 2016).

Azanza garckeana is a member of the Malvaceae family. The generic name "Azanza" is derived from the word "Azania", a word meaning black and surviving in Zanzibar. The specific name "garckeana" is in honour of Professor August Garcke (1819-1904), a German botanist and plant collector who specialized in pharmacognosy (Maroy, 2017).

\section{Botanical Classification of Azanza garckeana \\ Kingdom : Plantae - Plants}

$\begin{array}{ll}\text { Subkingdom } & : \text { Tracheobionta }- \text { Vascular plants } \\ \text { Superdivision } & : \text { Spermatophyta }- \text { Seed plants } \\ \text { Division } & : \text { Magnoliophyta }- \text { Flowering plants } \\ \text { Class } & \text { : Magnoliopsida - Dicotyledons } \\ \text { Subclass } & : \text { Dilleniidae } \\ \text { Order } & \text { : Malvales } \\ \text { Family } & : \text { Malvaceae - Mallow family } \\ \text { Genus } & : \text { Azanza } \\ \text { Specie } & : \text { Azanza garckeana }\end{array}$

English (common name) - tree hibiscus, azanza, snot apple Nigeria (Hausa): goron tula, Bostwana - morojwa South Africa - Thespesia garckeana (Mojeremane and tshwenyane, 2004; and Ochokwu et al., 2014).

\section{DESCRIPTION}

Azanza garckeana is a deciduous shrub; the tree can grow to a Height of $3-15 \mathrm{~m}$ high depending on the climate condition stem diameter at breast height of up to $25 \mathrm{~cm}$. The tree is multi-stemmed with straight or crooked stem, which is sometimes forking from the base. The bark is rough and greyish-black or brown, fibrous with longitudinal fissures. The twigs are hairy when young but become smooth with age and branches have woody hairs. The leaves are distinctively rounded, 8 by $12 \mathrm{~cm}$ on long stalks. They are always simple, alternate and roundish. The leaves have 3 to 5 lobes, which are covered in brown star-shaped hairs, and have longitudinal fissures in the midrib. The tip of the leave is usually bluntly pointed or rounded. The base of the 
leave is heart-shaped and is 5 to 7 nerved. The young leaves are brown in colour and velvety. The flowers are large up to $6 \mathrm{~cm}$ long, solitary on long pedicels in the axils of uppermost leaves, yellow with a purple-brown centre; the petals are globose and capsules are up to $4 \mathrm{~cm}$ long, the thickness is $3 \mathrm{~cm}$. the fruit is globose and have woody capsules of up to 3 to $4 \mathrm{~cm}$ in diameter, it is divided into 5 segments with each segment containing a seed, the remains of the calyx and epicalyx at the base; the seeds are hemispherical, up to $10 \mathrm{~mm}$ long, $7 \mathrm{~mm}$ thick, with brownish and woolly floss (Orwa et al., 2009).

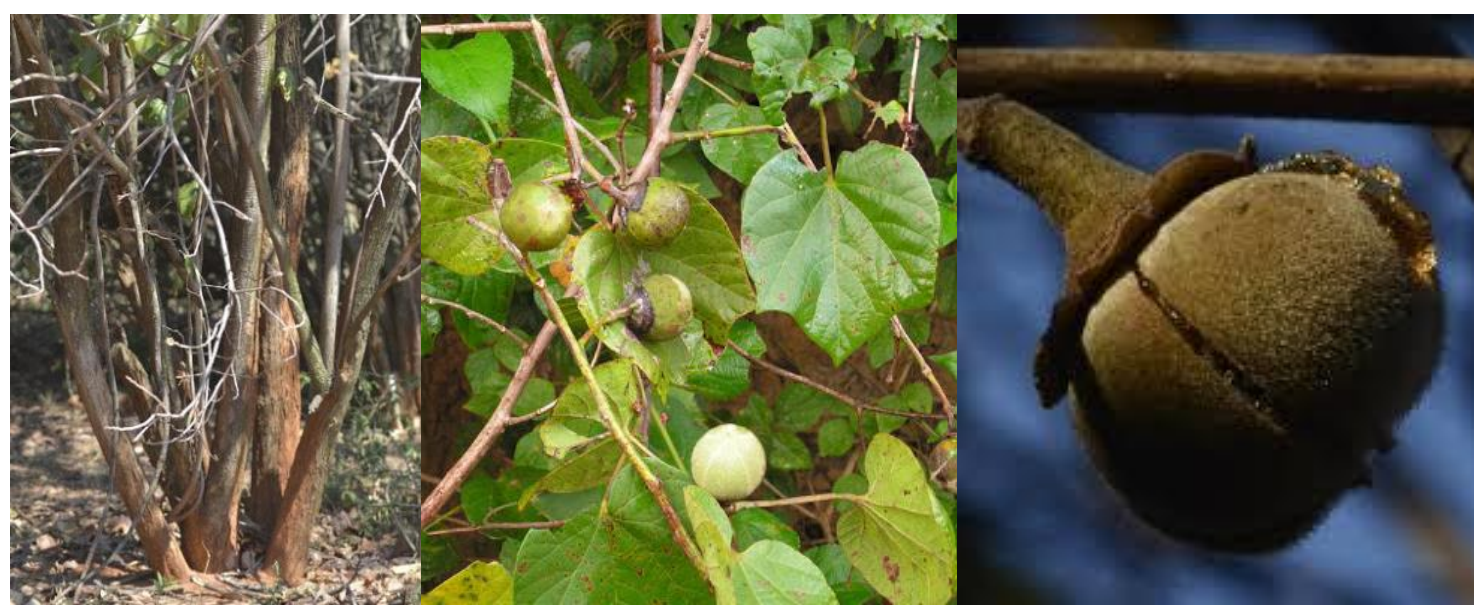
A. Shoot
B. Leaves and fruits
C. Mature fruit

Figure 1. Different parts of Azanza garckeana.

Table 1. Uses of Azanza garckeana.

\begin{tabular}{|c|c|c|}
\hline Medicinal use & Plant part(s) used & Country practised \\
\hline \multicolumn{3}{|l|}{ Dietary uses } \\
\hline Edible fruits & Fruits & $\begin{array}{lrr}\text { Botswana, } & \text { Kenya, } & \text { Malawi, } \\
\text { Nigeria, } & \text { Sudan, } & \text { Tanzania, } \\
\text { Zambia, Zimbabwe } & \end{array}$ \\
\hline Food additive & Fruits & Sudan, Tanzania \\
\hline \multicolumn{3}{|l|}{ Medicinal uses } \\
\hline Abscesses & Fruit poultice applied & Nigeria \\
\hline Anemia & Ripe fruits & Sudan \\
\hline Antiemetic & Root infusion taken orally & Zimbabwe \\
\hline Aphrodisiac & Ripe fruits taken orally & Nigeria \\
\hline Asthma & Root decoction mixed with Sterospermum kunthianum Cham. & Malawi \\
\hline Chest pains & Root infusion taken orally & Nigeria, Zimbabwe \\
\hline Cough & Root infusion taken orally & Kenya, Nigeria, Zimbabwe \\
\hline Diabetes & Leaf decoction taken orally & DRC \\
\hline Earache & Root infusion dropped into ear & Zimbabwe \\
\hline Edema & Leaf decoction taken orally & DRC \\
\hline Epilepsy & Leaf decoction taken orally & DRC \\
\hline Fever & Root decoction taken orally & Malawi \\
\hline Gonorrhoea & Roots and stem bark taken orally & Malawi, Nigeria \\
\hline Induce & labour Root decoction taken orally & Tanzania \\
\hline Infertility & Ripe fruits or root decoction taken orally & Botswana, Malawi, Nigeria \\
\hline Liver problems & Stem and leaf decoction taken orally & Kenya, Nigeria \\
\hline Madness (mental illness) & Root decoction taken orally & Zimbabwe \\
\hline Malaria & Eat raw fruit or cook and eat as relish & Zambia \\
\hline Membrane rupture & Root decoction taken orally & $\mathrm{DRC}$ \\
\hline Menstruation & Root infusion taken orally & Nigeria, Zimbabwe \\
\hline Retained placenta & Root infusion taken orally & Zimbabwe \\
\hline Sexually transmitted diseases & Root and bark infusion taken orally & Zambia \\
\hline Syphilis & Root decoction taken orally & Nigeria \\
\hline
\end{tabular}


Table 2. Compounds extracted from Azanza garckeana.

\begin{tabular}{|c|c|c|}
\hline Compounds & Extract & $\begin{array}{l}\text { Plant } \\
\text { parts }\end{array}$ \\
\hline \multicolumn{3}{|l|}{ Sesquiterpenoids } \\
\hline $\begin{array}{l}\text { Gossypol, } \\
\text { 6, 6-Dimethoxygossypol, } \\
\text { 6-Methoxygossypol }\end{array}$ & $\begin{array}{l}\text { Ethyl acetate in n- } \\
\text { hexane; methanol } \\
\text { in dichloromethane }\end{array}$ & Root \\
\hline $\begin{array}{l}\text { Phytosterol } \\
\text { Stigmasterol }\end{array}$ & $\begin{array}{l}\text { Ethyl acetate in n- } \\
\text { hexane; methanol } \\
\text { in dichloromethane }\end{array}$ & $\begin{array}{l}\text { Root and } \\
\text { Stem bark }\end{array}$ \\
\hline $\begin{array}{l}\text { E-docosyl 3-(3, 4- } \\
\text { Dihydroxyphenyl) } \\
\text { Acrylate }\end{array}$ & $\begin{array}{l}\text { Ethyl acetate in n- } \\
\text { hexane; methanol } \\
\text { in dichloromethane }\end{array}$ & $\begin{array}{l}\text { Root and } \\
\text { Stem bark }\end{array}$ \\
\hline O-naphthoquinones & n-hexane & heartwood \\
\hline $\begin{array}{l}\text { Mansonones E, F, G, H } \\
\text { Azanzone A, B }\end{array}$ & n-hexane & heartwood \\
\hline \multicolumn{3}{|l|}{ Triterpene } \\
\hline Betulinic acid & $\begin{array}{l}\text { Ethyl acetate in n- } \\
\text { hexane; n-hexane; } \\
\text { methanol in } \\
\text { dichloromethane }\end{array}$ & $\begin{array}{l}\text { Fruit } \\
\text { pulp, root, } \\
\text { stem bark }\end{array}$ \\
\hline
\end{tabular}

Dikko et al., 2016 \& Maroyi, 2017
Azanza garckeana is widely distributed in the east, west and southern Africa. It generally grows naturally in all types of woodlands from sea level to about $1700 \mathrm{~m}$ above sea level. It also grows in semi-arid areas. Azanza garckeana grows in a variety of soils and is found near termite mounds and deserted areas while in Nigeria it grows in open woodland in the north eastern part of the country (Ochokwu et al., 2015). Azanza garckeana (Goron Tula) as an Edible Indigenous Fruit in North Eastern Part of Nigeria (particularly Gombe State).

FAO (1983) reported that A. garckeana grows naturally in semi-arid areas receiving annual rain fall that range from $250 \mathrm{~mm}$ to $1270 \mathrm{~mm}$. Flowering takes place during the raining season, while fruit ripening occurs during the dry season, hence it takes about six months from flower fertilization to ripening of the fruit. In Southern Africa, flowering occurs from December to May and fruiting from February to September while in North Eastern Nigeria flowering occurs from May to October and fruiting/ripening from November to April (Ochokwu et al., 2015).<smiles>C=CC1=C(O)C(O)=C(C(C)C)C2C=C(C)C(c3c(C)cc4c(C(C)C)c(O)c(O)c(C=O)c4c3O)=C(O)C12</smiles><smiles>CC1=C2OCC(C)c3c(O)cc(C)c(c32)C(=O)C1=O</smiles>

mansonone $\mathrm{H}$<smiles>CC1=Cc2c(C(C)C)ccc(C)c2C(=O)C1=O</smiles>

mansonone $\mathrm{C}$<smiles>CC1=Cc2c(c(C)cc(O)c2C(C)C)C(=O)C1=O</smiles>

mansonone $\mathrm{G}$<smiles>CC1=Cc2c(C(C)C)cc(C)c(C)c2C(=O)C1=O</smiles>

azanzone<smiles>CC1=C2OCC(C)c3ccc(C)c(c32)C(=O)C1=O</smiles><smiles>CCC(/C=C/[C@H]1CCC2C3CC=C4CC(O)CCC4(C)[C@H]3CC[C@@]21C)C(C)C</smiles>

Stigmasterol<smiles>CC(C)[C@H](C)CCC[C@H]1CCC2C3CC=C4CC(O)CCC4(C)C3CC[C@]21C</smiles>

Phytosterol

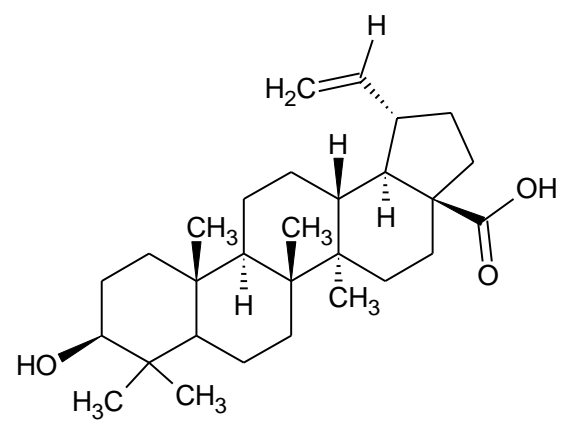

Butulinic acid<smiles>O=C1C=Cc2ccccc2C1=O</smiles>

o-naphthoquinone

Figure 2. Some compounds Isolated from Azanza garckeana. 


\section{EFFECTS OF CHEMICALS EXTRACTED FROM Azanza garckeana}

Mansonone $\mathrm{E}, \mathrm{C}, \mathrm{G}$ and $\mathrm{H}$ displayed antifungal activity against $P$. parasitica, with Mansonone E showing the highest activity. Also suggests potential Mansonone E as a new natural pesticide for agricultural plant pathogen management. (Mongkol1 and Chavasiri, 2016).

A Computational and Experimental Study carried out on the anticancer ability of mansonone $G$ by $\beta$ Cyclodextrin-Based Host-Guest Complexation revealed that The inclusion complex formation between Mansone $\mathrm{G}$ and $\beta$-Cyclodextrin was confirmed by DSC and SEM techniques. Notably, the Mansone G/ $\beta$-Cyclodextrin inclusion complexes exerted significantly higher cytotoxic efect on A549 lung cancer cells than the uncomplexed Mansonone G (Mahalapbutr, 2019)

Anticancer Activity, Anti-HIV Activity, Antimalarial Activity was recorded for betulinic acid, it also shows pronounced antinociceptive properties, antiinflammatory activity (Moghaddam, 2012)

The effect of the terpenoids gossypol, 6methoxygossypol, 6,60-dimethoxygossypol, gossypolone and apogossypolone on growth of fungal soil pathogens were investigated. Gossypol, gossypolone and apogossypolone demonstrated strong growth inhibitory activity $(\geq 90 \%)$ against Pythium irregulare, Pythium ultimum and Fusarium oxysporum. These same terpenoids provided good growth inhibition against most Rhizoctonia solani isolates. Methylated gossypol derivatives generally yielded reduced growth inhibition against the tested fungi compared with gossypol. Doseresponse effects of gossypol, gossypolone and apogossypolone were determined over a concentration range (Mellon, 2014).

Extracts from plants with high Phytosterol (stigmasterol and $\beta$-sitosterol) content is used in the treatment of inflammatory conditions and prevention of cancers and cardiovascular diseases (Ivanescu et al., 2013).

Sitosterols have been found to induce apoptosis when added to cultured human prostate, breast and colon cancer cells. Therefore, they may play significant roles in the management and prevention of human cancers. beta-sitosterol preparation improved symptoms, increased peak urinary flow, and decreased post-void residual urine volume. However, relatively few controlled studies have examined the efficacy of phytosterol supplements in men with symptomatic BPH. (Ogbe, 2015).

The plant has antifertility/contraceptive, antitumor properties (anticancer properties of gossypol against many types of cancer cell lines), Antioxidant properties, Antiparasitic properties, Antivirus properties, Antimicrobial properties, Plasma cholesterol reduction properties. (Keshmiri-Neghab \& Goliaei, 2014).

\section{CONCLUSION}

The various pharmacological activities of the chemicals extracted from the plant justifies the use of Azanza garckeana as plant effective for various diseases and health conditions, especially sexually trelated issues, as exposed by various researches. The use of the plant for further research will help to make even drug discovery.

Conflict of interest: The author declares that there are no conflicts of interest concerning the publication of this article.

\section{REFERENCES}

Dikko, Y. J., Khan, M. E., Tor-Anyiin, T. A., Anyam, J. V. and Linus, U. A. (2016). In vitro antimicrobial activity of fruit pulp extracts of Azanza garckeana (F. Hoffm.) Exell and Hillc. and isolation of one of its active principles, Betulinic acid. Br. J. Pharm. Res., 14: 1-10

Maroy, A. (2017). Azanza garckeana Fruit Tree: Phytochemistry, Pharmacology, Nutritional and Primary Healthcare Applications as Herbal Medicine: A Review. Res. J. Med. Plants, 11 (4): 115-123, 2017.

Musinguzi, E. L., Kikafunda, J. K. and Kiremire, B. T. (2007). Promoting indigenous wild edible fruits to complement roots and tuber crops in alleviating Vitamin A. deficiencies in Uganda. Proceedings of the 13th ISTRC Symposium.; 763769.

Nkafamiya, I. I., Modibbo, U. U., Manji, A. J. and Haggai, D. (2007). Nutrient content of seeds of some wild plants. Afr. J. Biotech. 6(14):1665-1669.

Aberoumand, A. and Deokule, S. S. (2009). Studies on nutritional values of some wild edible plants from Iran and India. Pak. J. Nutrition. 8(1): 26-31.

Nazarudeen, A. (2010). Nutritional composition of some lesserknown fruits used by ethnic communities and local folks of Kerela. Ind. J. Traditional Knowl., 9(2): 398-402.

Food and agricultural organization (FAO) (1983). Food and fruit bearing forest species. Examples from Eastern Africa. Food and Agricultural Organization, Forestry Rome.14-16.

Nkafamiya, I. I., Ardo, B. P., Osemeahon S. A. and Akinterinwa, A. (2016). Evaluation of Nutritional, Non-nutritional, Elemental Content and Amino Acid Profile of Azanza garckeana (Goron Tula). British Journal of Applied Science \& Technology, 12(6): 1-10.

Keshmiri-Neghab, H. and Goliaei, B. (2014). Therapeutic potential of gossypol: An overview. Pharmaceutical Biology, 52(1): $124-128$ https://doi.org/10.3109/13880209.2013.832776

Mellon, J.E., Dowd, M.K., Beltz, S.B. and Moore, G.G. (2014). Growth inhibitory effects of gossypol and related compounds on fungal cotton root pathogens. Letters in Applied Microbiology 59, 161-168.

Ogbe, R. J., Ochalefu, D. O., Mafulul, S. G. and Olaniru, O. B. (2015). A review on dietary phytosterols: Their occurrence, metabolism and health benefits. Asian J. Plant Sci. Res., $5(4): 10-21$

Mongkol1, R. and Chavasiri, W. (2016). Antimicrobial, herbicidal and antifeedant activities of mansonone $\mathrm{E}$ from the 
heartwoods of Mansonia gagei Drumm. Journal of Integrative Agriculture 15(12): 2795-2802.

Moghaddam, M. G. Ahmad, F. B. H. and Samzadeh-Kermani, A. (2012). Biological Activity of Betulinic Acid: A Review. Pharmacology \& Pharmacy, 3, 119-123.

Mahalapbutr, P., Wonganan, P., Charoenwongpaiboon, T., Prousoontorn, M., Chavasiri, W. and T. Rungrotmongkol (2019). Enhanced Solubility and Anticancer Potential of Mansonone $G$ by $\beta$-Cyclodextrin-Based Host-Guest Complexation: A Computational and Experimental Study, Biomolecules, 9: 1-17. doi:10.3390/biom9100545
Ivanescu, B., Vlase, L. and A. Corciova (2013). Importance of phytosterols and their determination in herbal medicines, The $4^{\text {th }}$ IEEE International Conference on E-Health and Bioengineering,

Ochokwu, I. J., Dasuki, A., \& Oshoke, J. O. (2015). Azanza garckeana (Goron Tula) as an edible indigenous fruit in North Eastern Part of Nigeria. Journal of Biology, Agericulture and Healthcare, 5(15), 26-31. 
THIS PAGE INTENTIONALLY LEFT BLANK 